\title{
6. On the Possible Deconstruction of the Swedish Drug Policy
}

Henrik Tham

Since 2006 the Stockholm Prize in Criminology has been awarded 'for outstanding achievements in criminological research or for the application of research results by practitioners for the reduction of crime and the advancement of human rights'. The prize is presented each year at a ceremony in Stockholm City Hall, usually by the Queen but sometimes by other official representatives of the state or the city. At the same time, the Swedish National Council for Crime Prevention organizes a symposium that opens with a panel where the Minister of Justice participates with the winners of the prize and other experts in discussing their research and views. In 2019, a renowned researcher on drug policy and a former President of Switzerland who has been active in harm reduction policy were awarded the prize. The year 2019 the Swedish state withdrew from both the panel debate and the prize ceremony.

Sweden has long been known as a 'hawk' in the war on drugs in comparison with other democratic countries in Europe. This reputation has hardly been seen as detrimental by Swedish governments, since the country has also claimed a successful drug policy. Fewer people than in other countries have tried drugs and the attitudes to drugs have been more negative. 'Sweden drug-free society' is the proud message that has been communicated both nationally and internationally.

Today, however, the situation is changing. Sweden's allied in the war on drugs, Norway, seems to be deserting by in a governmental

How to cite this book chapter:

Tham, Henrik. On the Possible Deconstruction of the Swedish Drug Policy. In: Retreat or Entrenchment? Drug Policies in the Nordic Countries at a Crossroads, edited by Henrik Tham, I29-I 58. Stockholm: Stockholm University Press, 202I. DOI: https://doi.org/Io.I6993/bbo.f. License: CC BY 4.0 . 
investigation proposing a policy that excludes the police practice of chasing drug users in the streets. Sweden has been criticized by the UN for not upholding human rights in its drug policy. No plans have been put forward regarding what to do about the rise in problematic drug use and drug-related deaths. Several countries have started on the road to decriminalization. Nils Christie's question (see Introduction, this volume) can then be asked: Has Sweden started a retreat and if not, why?

In an attempt to answer this question, we will start with a short description of Swedish drug policy since the I960s and its theoretical and political justifications. This will include the development of drug legislation, number of people sentenced for crimes related to drugs and drug consumption among school children - a central indicator in Swedish drug discourse. The results of the drug policy are then discussed in relation to indicators of the development of problematic drug use and drug-related deaths. This is then followed by a description of the costs of Swedish drug policy in terms of legislation, police interventions and imprisonment. Drawing the conclusion that the costs cannot justify the gains, an attempt is made to understand why the drug policy in Sweden is not changing in a direction that would be more effective and less costly.

\section{The Construction of Swedish Drug Policy}

In order to analyze the possible deconstruction of Swedish drug policy, it is necessary first to understand its construction. Drugs were identified as a social and political problem in Sweden in the I960s, thereby disengaging the issue from an earlier medical and individualized perspective (Edman \& Olsson 20I4). Changes in penal legislation at this time were aimed at the big producers, smugglers and dealers. The maximum penalty was, in a few years, raised to so years imprisonment, the then highest penalty in Sweden except the life sentence. Drug users were looked upon as victims and the debate about the users in the I970s concerned the issue of whether treatment should be voluntary or compulsory.

In the late I970s the policy changed. The Swedish parliament, in 1978, stated that society would not accept any use of 
narcotic drugs except for that which is medically motivated, and any other type of use would be strongly combated (Proposition I 977/78:105:30). This stand was later formulated as 'Sweden drug free society' (Proposition I983/84:I00), which became the motto for the drug policy. As a result of the zero-tolerance position, the General Prosecutor abolished the earlier praxis of waiver of prosecution for possession of small amounts for personal use. In I980, the Police launched a national campaign for arresting drug users in the streets (Brottsförebyggande rådet I983). The number of drug offences in the police statistics trebled in two years, mainly due to the police increasingly arresting already known drug users more often (Rättsstatistisk årsbok I993: I 47).

This development was followed by a political debate about criminalizing consumption as such. The center-right parties in Parliament pressed the Social Democratic government to criminalize use, which was done in I988 but only with a fine given as the penalty. The political opposition claimed that this was a useless law. Without imprisonment in the penalty scale the police had difficulties proving use. With the center-right parties in government a few years later, a law went into action in 1993 giving the police the right to take samples of body fluids by force in order to establish the use of drugs. The number of urine and blood tests carried out since then have increased sharply (Rättsmedicinalverket 2020). The number of drug offences reported to the Police in 2020 was I 24,000, an increase of more than four times since the law was passed in 1993 .

The increasing focus on the drug user meant that Swedish drug policy moved from supply prevention to demand prevention (Johnson 202I, p. II9 ff.). This change was influenced by a perception of the drug problem as an epidemic. The drug user was pictured as contaminating two or more others who, in their turn, would infect two or more, and so on. The drug user was also described as the only irreplaceable link in a chain of dealers, smugglers, producers and corrupt regimes in other parts of the world. If only just the users could be locked away, the whole pyramid would fall and the drug epidemic would come to an end (Bejerot I975; Johnson 202I). 
It was therefore argued that a strict policy directed towards the user was necessary. The policy was backed by a picture of drugs being a severe threat to the Swedish welfare state. This was the message of a doctor of social medicine, Nils Bejerot (I975), who was also the father of the epidemic theory. He was the central figure in the creation of the new drug policy and had hundreds of thousands of followers, in terms of the number of his books sold, articles written in the press and total audiences at his lectures. In I 979 he was bestowed the title of full professor by the center-right government.

The picture of drugs as a national threat to Sweden was supplemented by one of a successful policy. The Department of Justice seemed to have discovered that the proportion of school children using drugs was decreasing. After having stated in the central budget bill that drugs had emerged as one of the very largest social problems in the country (Proposition I983/84:100), two years later they stated that 'Sweden leads a conscious and resolute drug policy' (Proposition I985/86:100). The indicator of this claimed successful policy became the proportion of young people using drugs (Figure I4). The change in evaluating the development of drug policy could also be interpreted as a solution to a possible political problem. When the Swedish policy increasingly focused on the drug user by using penal law and the police, some success of this policy had to be demonstrated.

The claimed success of Swedish drug policy was spread in a government leaflet, which was translated into four languages (Swedish National Institute of Public Health I993). Even though the situation was serious, Sweden claimed a more successful drug policy than that of other countries (Swedish National Institute for Public Health I998). The climax of the claims, internationally, could be said to have been reached at the I998 UNGASS (United Nation General Assembly Special Session) in New York, where Sweden appeared with a large delegation, including the Queen, claiming a successful drug policy (Regeringskansliet I998).

From the turn of the century, however, fewer voices were raised to praise the Swedish drug policy. A government committee presented its report, At the Crossroads, in 2000 (SOU 2000:I26). Problems were admitted, such as the fact that an increasing 


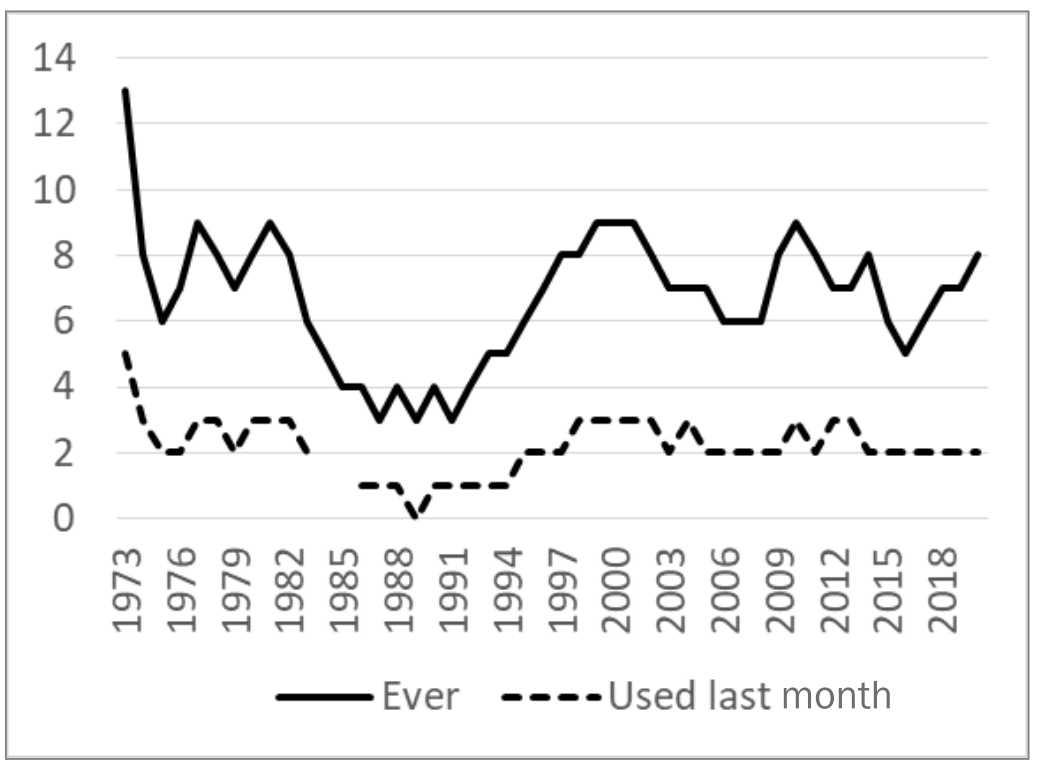

Figure 14. Proportion of pupils in 9th grade ( 5 years old) who have ever tried drugs and who have used drugs in the last month, I973-2020, percent.

Source: CAN (2020).

number of pupils had tried drugs, that the attitudes had become more permissive and that the mortality rate was high in relation to other countries. However, backing away from the restrictive Swedish model would mean 'lowered ambitions and the acceptance of considerable drug abuse' (op. cit.: II).

The government bill that followed the report reiterated the success of the Swedish policy, including in relation to other countries (Proposition 200I/O2:9I: I 5, 23). The general repudiation of drugs in the Swedish population was stressed and the number of new recruitments and mortalities among young people were said to be lower than in other comparative countries (op. cit.: IO). The concrete outcome of the bill was the appointment of a national drug policy coordinator. The office of the coordinator, 'Mobilization against drugs', existed for seven years before being closed down. The drug issue became less visible in politics and debate. It also disappeared from the election campaigns (Olsson 2OII; updated). It did, however, reappear in the 2018 parliament 
Table 15. Drug legislation, I967-2020.

\begin{tabular}{|c|c|}
\hline 1967 & Possibility for committal to psychiatric care for drug abusers \\
\hline 1968 & $\begin{array}{l}\text { Imprisonment for aggravated drug crime increased from a } \\
\text { maximum of } 2 \text { years to } 4 \text { years }\end{array}$ \\
\hline \multirow[t]{2}{*}{1969} & $\begin{array}{l}\text { Imprisonment for aggravated drug crime increased to a maximum } \\
\text { of } 6 \text { years }\end{array}$ \\
\hline & Phone tapping for aggravated drug crime introduced \\
\hline 1972 & $\begin{array}{l}\text { Imprisonment for aggravated drug crime increased to a maximum } \\
\text { of Io years }\end{array}$ \\
\hline I980 & Limitations of waiver of prosecution for possession of drugs \\
\hline I98I & $\begin{array}{l}\text { Imprisonment for normal drug crime increased from a maximum } \\
\text { of } 2 \text { years to } 3 \text { years } \\
\text { Imprisonment for aggravated drug crime increased from minimum } \\
\text { of I year to } 2 \text { years }\end{array}$ \\
\hline 1982 & Law on compulsory care for adult drug abusers \\
\hline 1985 & $\begin{array}{l}\text { Imprisonment for minor drug crime increased to maximum } \\
6 \text { months }\end{array}$ \\
\hline I988 & $\begin{array}{l}\text { Criminalization of consumption of drugs, maximum finer } 989 \\
\text { Increased time from } 2 \text { to } 6 \text { months for psychiatric care for drug } \\
\text { abusers }\end{array}$ \\
\hline 1993 & Consumption of drugs, maximum imprisonment 6 months \\
\hline \multirow[t]{2}{*}{1999} & Expansion of criminalization of synthetic drugs \\
\hline & Zero tolerance for drugs in road traffic \\
\hline 2016 & $\begin{array}{l}\text { Extremely aggravated drug crime as new category in the Penal } \\
\text { Drug Law }\end{array}$ \\
\hline
\end{tabular}

election when gang-related shootings in deprived areas became linked to the sale of drugs.

Some changes of the drug policy, in the direction of harm reduction, have been undertaken since the turn of the century. Substitution programs have expanded markedly. Syringe exchange was accepted on a general basis by the Parliament in 2006 and lately, other harm reduction measures have also been introduced, such as the use of nasal spray against the risks of overdoses and medical marijuana, albeit slowly and both on a restrictive base. 
The dominating picture of Swedish drug policy is, however, a development in an increasingly strict direction. Penal and other types of compulsory legislation have expanded markedly, and so have both the numbers of crimes reported to the Police and sentences meted out in the criminal justice system. This is shown in Table I 5 and Figure I 5 .

\section{Has Swedish Drug Policy Been Successful?}

The expansion of penal law, reported crimes, police resources and sentences could perhaps be justified if this had led to a decrease in the damage and suffering caused by drug use. This is the position taken by various governments claiming the relative success of Swedish drug policy. This possible success is, however, limited to the comparatively low proportions in the population that have ever tried drugs, use them recreationally or who are favorable to the use of drugs. These indicators refer to use and attitudes, not to problematic use in terms of social malfunctioning, sickness or death. Here the picture becomes different.

In Sweden, three case-finding studies of 'heavy' or problem drug use were carried out in 1979, I992 and 1998. Estimates based on different indicators were then conducted up to 2007 (Olsson 201 I: 36-38). Estimates since then have not been presented, neither in Sweden nor by The European Monitoring Centre for Drugs and Drug Addictions, EMCDDA, for Sweden. The picture that emerges is a doubling of the absolute number with problematic drug use since the late I970s. The Swedish estimates at the beginning of the century are slightly below the European average as measured by EMCDDA.

Another measure of detrimental drug use is drug-related mortality. The Swedish figures can be compared both historically and with other countries. Figure I 6 shows the development of drug-related mortality since I969. The increase is considerable. The causes of the particularly sharp increase in the I990s followed by a decrease in the early 2000 s and then by a continued expansion is a matter of debate. First, a decline in resources for treatment after the economic crisis in the early I990s and then an expansion of substitution programs has been mentioned. 


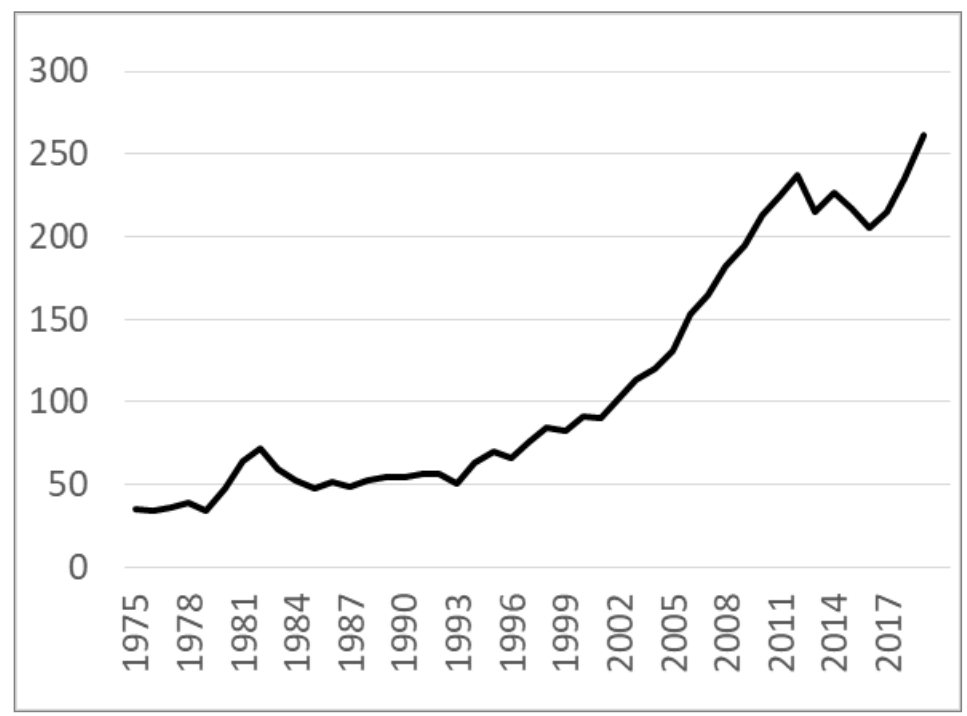

Figure 15. Number of people sentenced for drug crimes as major crime, I975-2019, per I00,000 inhabitants.

Source: Kriminalstatistik.

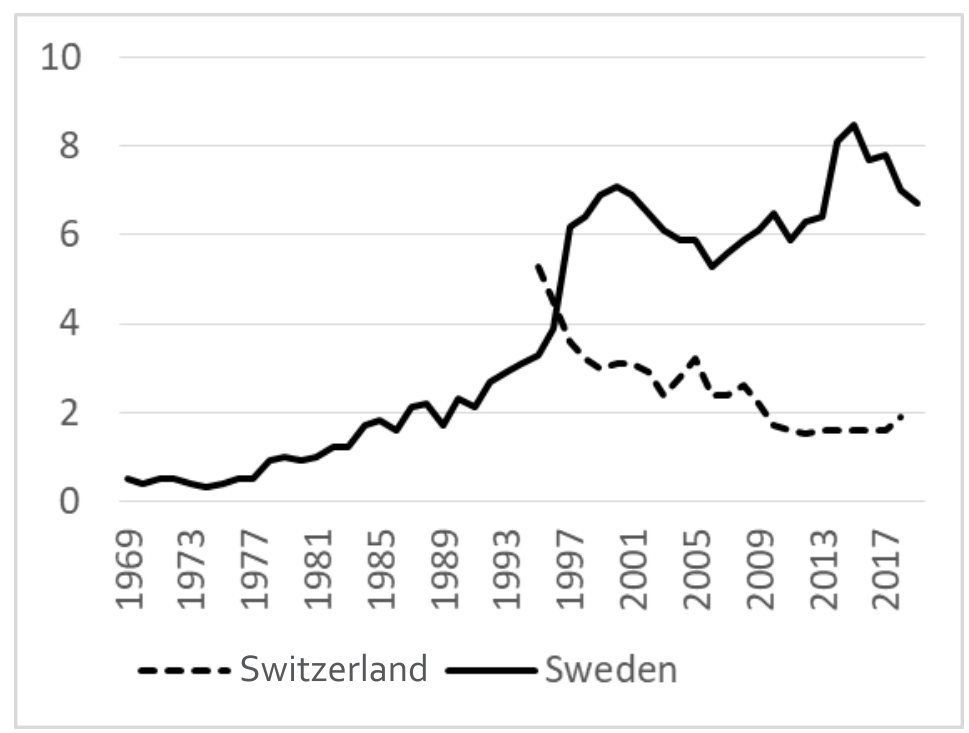

Figure 16. Drug-related mortality in Sweden, I969-2019, and Switzerland, I995-2018, per I00,000 inhabitants.

Source: CAN (2019) (updated); Swiss Health Observatory. 
These explanations are of less importance to the overall development of drug-related mortality. Even the secular trend, however, has been a matter of debate. Inclusions and exclusions of various drugs in the definition of drugs have affected the speed of increase. A study of the development of drug-related deaths concluded that the rise is considerable even though the sharp increase at the years before 2015 is exaggerated (Leifman 20I6). That there is a marked rise is also compatible with the fact that there has been a rise in the number of people who are considered as having a 'heavy' or problematic pattern of drug use.

Drug-related mortality in Sweden is also one of the highest in Europe (EMCCDA 2019). Figures from Switzerland are included in Figure I6, showing that an increase is not an unavoidable development taking place everywhere in Europe - a fact that the Swedish Minister of Justice was not prepared to discuss in connection with The Stockholm Prize in Criminology 2019. Switzerland showed a marked increase in drug-related deaths up to the early I990s, but the trend then took a downturn with a change in drug policy (De Preux, Dubois-Arber, \& Zobel 2004). In relation to other European countries there are, of course, difficulties involved in doing comparisons. The Swedish government is quick to point this out when criticized for the high number of deaths (Swedish drug policy nd.:9). Sweden might also be making a rod for its own back by looking particularly carefully for indications of drugs in classifications of causes of death. Despite reservations of the possibility of making comparisons, a report to the Swedish government has admitted the high rate of drug-related deaths in relation to other countries in Europe (SOU 2000:I 26), which has been reiterated as late as 202I (Proposition 2020/2I:I2I).

\section{The Costs of the Control of Drugs in Sweden}

In politics, possible gains must be balanced against possible costs. In making an evaluation of different measures of reducing drug abuse, the costs of these measures have to be included. Typical costs refer to the penal legislation and to the criminal justice system, like resources spent by the Police, the prosecutors and the courts, and the number of people in prison for drug crimes, both in terms of economic costs and suffering for those in prison. As 
costs related to the criminal justice system can also be counted, different types of discriminatory praxis and violations of integrity by the police should also be considered.

Penalization of an act is, in law, traditionally seen as a last resort, as a cost in itself, that should always be seriously considered before undertaking (Jareborg I995). In the preparatory works from the Department of Justice that gave the Police the right to take blood and urine tests by force, it was pointed out that it was 'principally wrong to criminalize an act that was directed against the person him- or herself' (Ds I 992:19:28).

The fact that using drugs, in itself, is a criminal offence in Sweden is a violation of this principle. It also produces a large number of crimes and criminals. The National Council for Crime Prevention made a rough estimate of the number of crimes that occurred as a result of the consumption of drugs in 2015 and came up with a figure close to seven million crimes (Brottsförebyggande rådet 20I6: IO). The fact that the consumption of narcotic drugs is criminalized, an act without clear harm to others, has produced more than four times as many illegal acts as the total number of crimes reported to the Police. This can then possibly be regarded as a cost in terms of dark numbers or undetected crimes, the proportion of criminals in the population and recidivist rates.

Figure 17 shows the development of the number of years spent by the Police on drug cases in proportion to the total work force of police officers. The rise is particularly sharp from 1993, when the Police received the right to take samples of body fluids by force in order to establish the consumption of drugs. At most, the Police has spent almost one tenth of the total work force on drugs. The drop in the last few years can be attributed to a large police reform in 2015, however, whether it reflects a real drop in the use of police resources on combating drugs or just a change in registering activities is not clear. The drop in tests conducted by the National Board of Forensic Medicine is only seven percent and is back on the level it was at before the police reform in 2018 . The figure for 2020 is 42,000 tests, which is an all-time high (Rättsmedicinalverket 2020). Disregarding the dip, which might not picture a real decrease in police resources, the development of police hours and sentences is fairly similar (Figure I 5 ). Sentences 


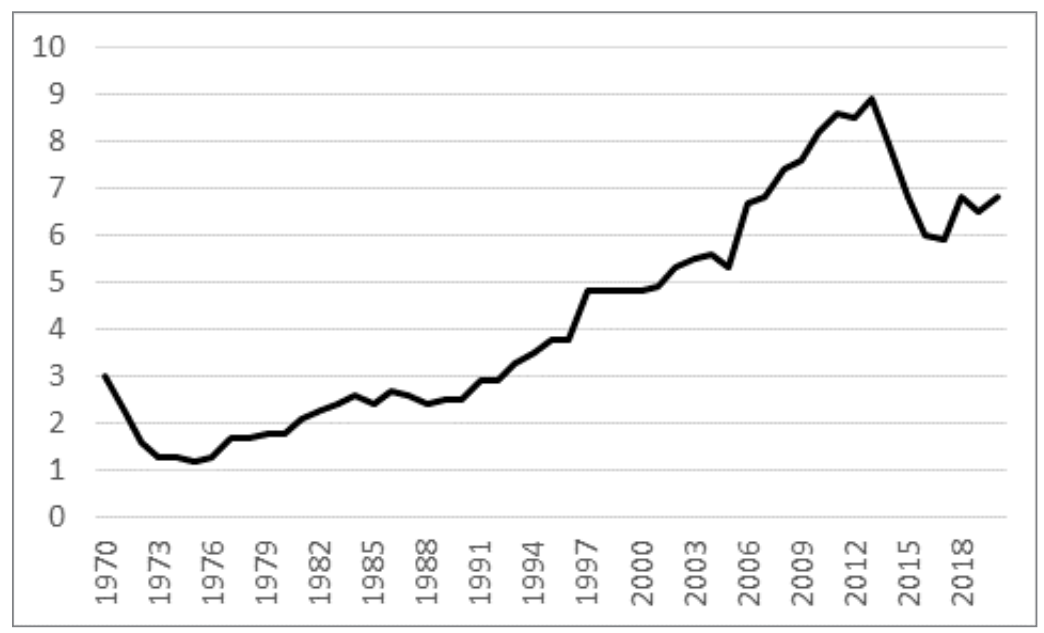

Figure 17. Number of years spent by the Police on drug cases in proportion to the total work force of police officers, I970-2020, percent.

Source: CAN (2019), updated.

seem then to be produced by the amount of police resources put in, as drug consumption is an almost inexhaustible source in terms of increasing the overall clearance rate.

The violation of integrity caused by this police practice might be experienced as particularly offensive if the suspected person has not consumed any drugs. The National Council for Crime Prevention (Brottsförebyggande rådet 20I6) has studied the urine and blood samples collected by the Police from I998-20I 5 that have been analyzed by The National Board of Forensic Medicine. It is shown that the number of false positives increased during the period from io to around 20 percent. The false positives were also, throughout the period, by far the highest in the youngest age group (I7 years), where they were close to half (op. cit.: I 8). The National Council for Crime Prevention stresses the problem that such a negative test might be the first contact with the criminal justice system for a number of young persons (op. cit.: 22).

Out of all prisoners who are serving time, more than one quarter has a drug crime, including smuggling, as the principal offence. The proportion was higher before a number of decisions in drug cases were made by the Supreme Court. Whether a sharpening of the law by the government in 2016 in order to reverse the 
decisions of the Supreme Court, and an announced sharpening by the government in 2019, will change this again remains to be seen. In addition, more than half of those in prison have been judged by the prison authorities to have a drug problem (Kriminalvården).

In a general expansion of the means of coercion available to the criminal justice system, the drug issue has played a central role. Secret wiretaps have been justified, particularly with reference to the suspicion of drug crimes. The wiretaps used quadrupled in Sweden from the I970s to the I980s - a development primarily explained by an increase in the police investigation of drug crimes (Svedberg \& Svensson I995). The majority of all wiretaps used concern drug crimes (Ds 2007:2). Since 2007, bugging has been legal in Sweden if there are suspicions of certain types of serious crimes. Central among these crimes are narcotic crimes.

The criminalization of drugs in itself produces criminality. The number of infractions caused by making the consumption of drugs illegal was mentioned above. The high economic costs of the consumption of narcotic drugs as compared to, for instance, the consumption of alcohol, can be expected to contribute to theft and other crimes against property. The high costs of drugs also lead to an illegal market where profits can be made. Such a market tends to be associated with high levels of violence. The case of Mexico is probably the most striking (Hari 20I 5 ).

A possible example from Sweden is the marked increase in shootings and homicides in socially deprived areas since 2013 . The causes of the shootings were the object of a study carried out by The National Council for Crime Prevention (Brottsförebyggande rådet 20I9), who interviewed young men who had been involved. The report discussing the causes of the conflicts states: 'The absolutely most common (cause) is that conflicts are tied to the drug market and particularly to the sale of cannabis ...' (op. cit.: 55 ). Several interviewees pointed out that they entered the criminal setting through the cannabis market - cannabis being so common in the socially deprived areas that no active introduction was necessary (op. cit.: I I6). The question could be raised as to whether the total ban on cannabis was a contributing cause of the fatal shootings.

Finally, there is the issue of discriminatory stop and search when it comes to drugs. The National Council for Crime Prevention 
conducted a study of young people in the Stockholm area comparing the distribution of suspects of drug use and drug use reported in anonymous surveys. The two indicators did not correlate as expected. Those from less wealthy areas, whose parents did not have higher education, who lived in rented flats and who were foreign born were more often suspected by the police for drug use. Drug use according to self-reported data, however, was more prevalent among those who lived in private houses in the richer areas, where at the same time fewer were suspected of drug use by the police (Brottsförebyggande rådet 2018; see also Holgersson 2007). In another study it was shown that the police discriminated against non-Europeans in stop and search on suspicion of drugs in Stockholm (Pettersson 2005).

Even though there can be other explanations to this outcome than direct discrimination from the side of the police, it could be interpreted as an example of procedural justice not being upheld. As such, an obvious cost of applied drug policy could be diminished respect for the criminal justice system and the negative consequences that have been reported to follow from this (Doobs \& Gartner 20I7: AI4). Regardless of discrimination, stop and search has, in several studies, been shown to create frustration and tensions between the police and citizens (op. cit.). Stop and search for whatever reason is also often justified by reference to the suspicion of drugs (Murray 20I4).

\section{Some Harm Reduction But Mostly a Fast Stand}

Given the questionable success of Swedish drug policy, and the high costs of this same policy, a change in the direction of policy might be expected. As mentioned, there have been some examples of a harm reduction policy. These policy changes have, however, originally met with resistance. A substitution program where heroin users were given Methadone was already set up in I966. In the early I980s, however, no new admittances were accepted as a result of an unholy alliance between different interests. There were those who feared a medicalization of a social problem, those who opposed harm reduction as giving the wrong signals, and groups from the political left who regarded substitution programs as a pseudo solution in a capitalist society exploiting people (Johnson 2003: I I7I 28). The program, however, was later allowed to expand again. 
Syringe exchange programs were also met with much resistance. Accepting syringe exchange was seen as a threat to the basic values of Swedish drug policy, and a program limited to two towns was the only one allowed as an experiment. The national drug coordinator worked hard to get the program accepted on a national level. The opposition was phrased in terms of risks of medicalization and that the goal of total rehabilitation would be abandoned. Syringe exchange was ultimately accepted by Parliament after guarantees of attaching social rehabilitation measures to the programs (Tham 2005:67 ff.). The programs were, however, still met by local resistance and further legislation was needed to get programs established (Proposition 2016/I7:I 5).

In spite of the introduction of some harm reduction measures, the main impression given is that of strong resistance to liberalizing the drug policy in Sweden. In a survey before the general election 2018 , the question was put to the political parties of whether they were willing to decriminalize the use of narcotic drugs. Only the Left party was in favor of changes in that direction. None of the parties wanted to legalize drugs. When it came to penalty scales, most parties wanted to stay with the present legislation, with the Moderates (liberal-conservative) and the Social Democrats wanting to increase the severity of prison sentences, and the Left party wanting to consider lower prison sentences (Andersson \& Ekeroth 2018).

In the party programs there is strikingly little about drugs. Neither has there been much on drugs in earlier party programs, although a number of special reports and information folders were published earlier. The relative lack of action today could be interpreted as the parties being on the defensive with regards to the drug issue. They do not want to leave the motto 'Sweden drug free society' behind, but at the same time, do not really know how to develop an effective drug policy. When the word 'drugs' appears in the party programs it is mainly used as a way of underlining the general seriousness of the crime problem. The Social Democrats in particular use drugs as an intensifier in statements about the threat of crime against the country. In the criminal policy program of the party, drugs are mentioned nine times and in general alarmist contexts: 'Shootings and open drug trafficking have been a problem for a long time', 'Problems with gangs of 
thieves, an increase in reported sex crimes, and drug crimes are examples of problems that are found in all our country', 'Drug dealing, shootings, threats and violence have to get away from our streets' (Socialdemokraterna 2018).

The political parties watch each other for signs of liberalization of the drug policy, which are then used politically. Critique from non-political bodies could possibly, then, be used as an opportunity to look for new roads to take. In a number of rulings starting in 20I I, the Supreme Court lowered the sentences for aggravated drug crimes. This was, however, not silently accepted by the government. First the center-right government and then the Social Democratic-Green government reacted against the new praxis of the courts and increased the penalty scale with a new category, 'extremely aggravated drug crime' (Proposition 20 I 5/I 6:I I I).

The government, in a report to UNGASS 2016, explicitly defended why Sweden has criminalized drug consumption (Swedish drug policy nd.: 7). In a government communication on the strategy for alcohol and drug policy 2016-2020 the goal of a drug free society was repeated (Regeringskansliet 20I6). The Social Democratic-Green government has declared that it will raise the penalty for drug crimes. In 2019, the government commissioned the Police to intensify its work against drug dealing (Justitiedepartementet 20I9). The Minister of Social Affairs has, in 2020, refused evaluations of the law criminalizing consumption after recommendation both from the Parliament and the Public Health Authority. Finally, in an introduction to a conference on drug treatment held by Swedish regions in 2020, the Minster of Justice declared that he would not accept a decriminalization of consumption, that drugs are the roots of organized crime, that a decriminalization would be an enormous gift to the criminals and that the critics should speak up about their real motives for liberalization (Johansson 2020).

\section{Obstacles to Change}

The question to be raised then is why Sweden sticks to its old policy, a policy that also seems foreign to the general pragmatic politics of the country. A number of conditions and processes partly linked to each other can be distinguished. 


\section{A drug free society}

The motto 'Sweden drug-free society' formulates possible positions in the drug policy debate as binary. It is either/or. You are against drugs or you are for drugs if you do not embrace the official motto. It makes it more difficult to try pragmatic, harm-reducing reforms. Such reforms, and particularly reforms in the direction of decriminalization, have been labelled 'a catastrophe' by the Ministeer of Social Affairs (Wallström I998). Resistance against substitution programs and syringe exchange has been expressed in terms of not being compatible with the basic values on which the Swedish drug policy is founded. The 'Sweden drug-free society' perspective will not permit any distinctions between different types of narcotic drugs. The distinction between soft and hard drugs has officially been rejected by the government (Swedish National Institute of Public Health I998:9). Those in the debate who have tried to articulate the difference have been accused of being 'soft on drugs'. The zero-tolerance foundation of Swedish drug policy has, in itself, become an obstacle to possible rational solutions to a social problem.

\section{The tradition from the Temperance movement}

That the prohibitionist Swedish drug policy has its parallel in the Temperance movement has been pointed out in an analysis by Leif Lenke (I99I). This movement had been quite strong in Sweden, however, after losing ground since the I960s it gradually incorporated the drug issue. The zero-tolerance tradition of the Temperance movement, with total abstinence from alcohol, also became the approach to narcotic drugs. The Temperance movement was in conflict with the official Swedish alcohol policy of regulated drinking through price policy and a rationing system. The theoretical foundation of this stand was the stepping-stone or gateway theory. The use of alcohol in any form, even of low strength, meant a risk - a risk of continued consumption. Beer led to hard liquor and therefore was condemned. The equivalence when it came to narcotic drugs, then, was that cannabis smoking led to hard drugs and social exclusion, and therefore had to be fought particularly hard.

The gateway theory has not been empirically supported when it comes to the development of drug use in Sweden. Low prevalence 
or incidence of drug use has not been followed by a low number of people with problematic use or a low level of drug-related deaths. In comparison with other European countries, several have higher levels of recreational drug use without having as high levels of drug-related deaths as seen in Sweden (EMCDDA 20I9). Still, the theory is used to justify a zero-tolerance drug policy. The indicators 'ever tried drugs' or 'have used drugs in the last month' continue to be referred to as proof of a successful drug policy.

\section{The interventionist tradition}

Identifying social problems and acting upon them with reforms is central to social engineering and the welfare state. Non-intervention is alien to this type of thinking. When the political parties before the election in 2018 were asked if they would consider decriminalization of the consumption of drugs, two of them, The Liberals and The Christian Democrats, said no to decriminalization but would consider changing the penalty to rehabilitation (Andersson $\&$ Ekeroth 20I 8). That people who use cannabis on a limited scale might not need drug treatment was not seen as an option.

The interventionist tradition could partly be understood against the background of the economic commitment of the welfare state to its citizens. The welfare state promises to take care of those who cannot take care of themselves. When unable to work because of sickness, disability, parental care or old age, for example, comprehensive social insurances will grant a reasonable standard of living. Such a system is costly and demands that as many people as possible work and contribute with taxes. The prospect that someone will never even enter the labor market because of heavy use of drugs and will need social allowances for his or her whole life might contribute to interventions, and sometimes even coercion.

This interventionist tradition is also related to a tendency to consider human rights in positive terms, stressing quality of life, rather than in negative terms, stressing the protection against the state. In the political debate in the I980s about criminalizing consumption, the leader of The Liberals (then The People's Party) was pictured full size on advertising signs declaring that in the country of The Peoples Party using dope would be illegal. For the defenders of the forced tests by the Police, the question of 
whether the state has any business examining the urine of its citizens has not occurred.

Before UNGASS 2016 Sweden was, as mentioned, criticized by the UN for not upholding the human rights of drug users (The Local 20I 5). The answer from the Swedish government gives a picture of how it perceives human rights and the duty of political interventions.

The UN Convention on the Rights of the Child recognizes a child's right to grow up in a drug-free environment as a human right. The UN International Covenant on Social, Economic and Cultural Rights talks about the right to health. All societies attempt to protect their citizens from risks that they cannot foresee; these may be anything from additives in food to seat belts in cars. This is part of the duty of society and of governments to protect citizens from risks.

(Swedish drug policy nd.:9)

The Swedish government sets up two types of human rights against each other: the rights of the drug user as being protected against state force and the rights of children to grow up in a drug-free environment. Exactly how these two rights collide is not expounded. The document produced for the UNGASS also refers to the general duty of governments to protect its citizens from risks in connection with buying food and driving a car. In so far that such interventions justify penal law, it seems open to the possibility of fairly far-reaching restrictions on human rights as traditionally understood.

\section{A general law and order climate}

Sweden has moved in the direction of a criminal policy relying more heavily on punishment. Changes in the general criminal policy have been described in terms of an expansion of penal legislation, a shift towards an expressive approach to policy and symbolic legislation, an increasing stress on security, a pro-active Police and early interventions (Tham 2018).

These characteristics of the development are clearly shown in the drug policy. The expansion of penal law was shown in Table I 5. The expressive character of penal legislation regarding drugs is quite visible in the preparatory works. Legislation should give the right signals and show that society does not accept 
drugs. The issue of drugs also lends itself to symbolic criminal policy. Drugs are said to be a threat to Sweden, to democracy and the whole of society (Tham 2005). Such statements also fit well with the increasing stress on security in Swedish politics (Hermansson 20I9). The rule of law has had to yield for security concerns, and 'unconventional police methods' have expanded with reference to drugs. Early interventions and pro-active policing are consequences of the overall strategy for criminal policy: crime prevention. In the case of drugs, for example, a law now gives the possibility for mandatory drug tests of legal minors (Proposition 2009/IO:I05).

The parallel development of criminal policy, in general, and drug policy is clear. The general development in the direction of a policy relying increasingly on punishment could therefore be seen as an obstacle to a liberalization of the drug policy.

\section{A punitive public?}

In the document presented by Sweden to UNGASS 2016 it was pointed out that the drug policy has been formed from below: 'Sweden's drug policy has been firmly established for a long time, both across political boundaries and with support of the Riksdag (the Parliament), but also through strong support from the general public' (Swedish drug policy nd.: 2).

In the process of criminalizing the pure consumption of drugs, popular support was claimed by referring to a survey sponsored by Lion's Club where 95 percent of the interviewed population agreed that all dealings with drugs ought to be prohibited (SIFO I984). In the I980s, the theme of the people vs the liberal elite was also clearly present in the drug discourse, and it was claimed that there was popular support for a tougher drug policy (Tham I995: II7 f.).

If this is the case, Swedish drug policy could be said to be an example of democracy at work (Beckett I997). This view can, however, also be questioned and systematic empirical support of a pressure from below is lacking. Most people would have rather limited knowledge of drugs - as compared to alcohol - and would therefore have to rely on the analyses put forward in the public debate. The picture provided of the drug situation is, to a 
high extent, put forward from above: from politicians, the Police, experts, NGO's and the media. In the government bill launching a national drug coordinator in 2002, one of the tasks of the coordinator was to carry on public opinion work, engage authorities and youth organizations, and 'offensively' propagate the official policy of the government (Proposition 200I/O2: 9I, 90 f.). Alcohol, narcotics, doping and tobacco programs (ANDT) have also worked for several decades in schools.

A study of the Swedish drug policy carries the subtitle, The opinion machine at work (van Fessem I996). The author writes:

Public opinion doesn't appear out of the blue. Opinions are shaped by history and previous experiences. And in the Swedish case, opinions are shaped through 'opinion formation' by the government institutions. The National Institute for Public Health (Folkhälsoinistitutet) has a central role to play in the process of opinion formation.

(op. cit.: 7I)

The report also lists a number of other authorities, private companies and NGOs that have been involved in forming the zero-tolerance stand against drugs in Sweden.

Even if the framing of the drug problem comes from above rather than from below, it could be effective and constitute an obstacle to a liberalization of Swedish drug policy. Such concerns have been voiced. After more than 40 years of 'Sweden drug-free society', an intense zero-tolerance policy and massive information from the government and pressure groups, the public might not be swayed that easily.

\section{Drug control as a national project}

In criminological analyses of criminal policy there is a long tradition of interpreting development of policy in terms of possible latent functions. Theses explanations usually take the form of a national discourse (Cohen I972; Gusfield I963; Hall et al. 1978). A sharp and uncompromising reaction to a form of deviant behavior, and out of proportion to the seriousness of the problem, is seen as a means of strengthening a threatened national identity.

Magnus Linton makes such an interpretation of the tremendous popularity and influence of the leading figure of drug policy 
in Sweden, Dr. Nils Bejerot. Drug use was, according to Bejerot, the most important sign of decadence following the lack of norms that was the result of 1968 . The conscientiousness of the people of the working class who had built the Swedish welfare state was said to be challenged by dopes, sex liberalists, pop radicals and lovers of thievs - all alien to traditional Swedish culture. Bejerot then managed to focus the anxiety of large groups on the drug issue after the radical, and even revolutionary, I968 and the stagnating economy after the oil shocks in the I970s. The whole welfare state was said to be threatened but could still be saved if a strict policy of punishment and isolation was applied to people on drugs (Linton 201 5: chap. I).

The Swedish drug policy and discourse in the I970s and early I 980 os developed further but with a slightly different focus. The concept of 'The Swedish model', which earlier referred to an active labor market policy and generous social insurances, somewhat lost its ring in the I980s when, along with the welfare state idea, it started to be questioned. The concept was then given a new meaning, referring to the Swedish drug policy. Swedes united behind a new model and explicitly tried to export it to other countries. The importance of making a stand against drugs became formulated in relation to 'the foreign': drugs are un-Swedish, drugs are not compatible with traditional Swedish morals, both drugs and ideas of liberalization come from abroad, and the solution to drug abuse would be farm work and mounting hiking in the north of Sweden. The control of drugs in Sweden could be seen as a national project when the welfare state project became less self-evident. A strict drug policy became a way of reinforcing Swedish-ness (Tham I995).

\section{Retreat?}

The official line of the government is still 'Sweden drug-free society', repeated by the government in the action plan for $202 \mathrm{I}-$ 2025 for alcohol, narcotic drugs, doping and tobacco (Proposition 2020/2I:I32). A governmental investigation in August 202 I presented a report proposing increased penalties for drug dealing after directives from the government (SOU 202 I:68). Both the Minister of Justice and the Minister of Social Affairs have, as 
mentioned above, come out quite explicitly against any type of decriminalization. A number of obstacles to a more liberal drug policy were also pointed out above: the claimed success of the drug policy and its nationalistic undertones, the long-term and massive anti-drug information from the government and NGO's and its influence on the public, the tradition from the Temperance movement and the gateway theory, and the aversion in a welfare state to not intervene actively in anything that is regarded as a social problem. So, returning to the question asked by Nils Christie: 'How will the retreat be organized', it presently looks like Sweden will not retreat but will continue the war on drugs and will fight decriminalization and legalization.

However, there are also signs and circumstances pointing towards a liberalization of the drug policy in Sweden. Organizations have been formed combating the official zero-tolerance policy (Föreningen Tryggare Ruspolitik). Debates are taking place in the national press and on the internet (Månsson 20I7). Programs are appearing in the national television on the issue of decriminalization. The youth organizations of the political parties are nearly all in favor of decriminalization, with two even in favor of the legalization of cannabis.

The claim that the people want a strict drug policy could be questioned. A study of the general sense of justice in relation to different crimes in all the Nordic countries (Balvig et al. 2015) did not indicate a punitive population in relation to drug crimes. In Sweden, the result of a national vignette survey was that the population, on average, propose sentences far below that of the courts. In a focus group study including a video of a mock trial, where the accused had smuggled 250 grams of heroin and the judges wanted to give a five-year prison sentence, half of the participants opted for an alternative punishment to imprisonment (Jerre \& Tham 20I0). The people, if properly informed, would perhaps not be an obstacle to decriminalization.

Even public organizations and authorities have begun to question the present drug policy. Sweden's municipalities and county councils (SKL, Sveriges kommuner och landsting 2018) has demanded an evaluation of the law criminalizing drug consumption and an international comparison. In 2020 the Public Health Authority, the governments expert authority on drug policies, 
published its report on the drug strategy for the next four years. It underlines the importance of syringe exchange as a probable means for reducing drug-related deaths and also suggests an investigation of the possibility of monitored drug consumption rooms as a further means for this purpose. The Authority also proposed an evaluation of the law criminalizing the consumption of drugs (Folkhälsomyndigheten 2020).

The Standing Committee on Social Affairs in the Swedish Parliament in February 2020 unanimously decided to demand an inquiry into the drug policy by the government. That such an announcement could be put forward at all is a result of the government parties not being in the majority in the Parliament, and the demand therefore became a decision by the Parliament. The committee, in its report, emphasized evaluation, treatment, harm reduction and a zero-tolerance vision for drug-related deaths (Socialutskottet 2019/20). The Minister of Social Affairs from the Social Democrats and the Social Democrats in Parliament, however, opposed an evaluation of the criminalization of consumption. An evaluation plan has still, more than one year after the announcement from the Parliament, not been presented. All in all, however, there has been a clear change in the debate on drug policy in the political parties during just a few years.

Finally, and hypothetically, a liberalization of the drug policy might have unintended consequences. Not only has the drug policy followed the general trend towards law and order, as was pointed out above, but it has also taken the lead in this development. Means of coercion and a pro-active Police have been justified with reference to the drug menace. The use of the whole penalty scale in sentencing for drug crimes has become a point of reference for politicians criticizing the courts for staying in the lower end of that scale. The general move towards expressive justifications of penal legislation has become a forerunner in drug legislation. The claimed organized crime behind drugs is now said to characterize almost every type of crime (Tham 20I2).

Could reversing the punitive trend in drug policy then be expected to influence criminal policy in general? A return to the rule of law, proportionality and ultima ratio as principles of criminal legislation in drug cases could have effects in general. A reduction in the length of prison sentences for drug crimes would markedly 
lower the prison population. The recognition that more than half of those in prison are judged to be drug-abusers with a particularly difficult background could perhaps restore the insight of the typical prisoner as being socially disadvantaged, and not just a villain who refuses to take responsibility for himself and his acts.

This line of argument could then again be an obstacle to changes. Taking drug policy seriously means facing questions regarding classic principles of law, the right to privacy and self-determination, the roots of marginalization and social exclusion, and the costs of penal control. The years to come will show if Sweden is prepared for such a turn in criminal policy.

\section{References}

Andersson, N., \& Ekeroth, E. (2018-08-30). Så vill riksdagspartierna forma narkotikapolitiken. Accent. http://www.accentmagasin .se/politik/sa-vill-partierna-forma-narkotikapolitiken/.

Balvig, F., Gunnlaugsson, H., Jerre, K., Kinnunen, A., \& Tham, H. (2OI 5). The public sense of justice in Scandinavia: A study of attitudes towards punishment. European Journal of Criminology, I2(3), 342-36I.

Beckett, K. (1997). Making crime pay. Law and order in contemporary American politics. New York: Oxford University Press.

Bejerot, N. (I975). Narkotika och narkomani. (3 updated editions). Stockholm: Aldus/Bonnier.

Brottsförebyggande rådet (I983). Polisens insatser mot gatulangningen av narkotika - ett utvärderingsförsök. Kansli-PM I983:9. Stockholm: Brottsförebyggande rådet.

Brottsförebyggande rådet (2016). Provtagning om misstanke om ringa narkotikabrott. En undersökning av analysresultat I998-20I5. Kortanalys I/20I6. https://www.bra.se/download /I 8.358 de305 I 533 ffea 5eadc492/I46I22I208545/20I6 _Provtagning\% 20vid\% 2omisstanke\% 200m\% 20ringa \% 20 narkotikabrott.pdf.

Brottsförebyggande rådet (2018). Narkotikaanvändning och misstankar om eget bruk bland ungdomar i Stockholm. Kortanalys 
2/20I 8. https://www.bra.se/download/I 8. Ioaae67f I 6oezeba 6292b7e9/I 52058I863937/20I8_Narkotikaanvandning_och _misstankar_om_eget_bruk_bland_ungdomar_i_Stockholm.pdf.

Brottsförebyggande rådet (2019). Skjutningar $i$ kriminella miljöer.

En intervjustudie. https://www.bra.se/download/I 8.62c6cfa2 I 66e ca 5 d 70 oe 35 5/I 549879I67358/20I9_3_Skjutningar_i_kriminella _miljoer.pdf. English summary: https://www.bra.se/download/ı 8 .62c6cfa2 I 66eca 5 d 70e404 I/I 55 I $859073659 / 20$ I 9_Shootings _in_criminal_milieux.pdf.

CAN. (2019). Drogutvecklingen i Sverige 2019. Rapport I80. https://www.can.se/Publikationer/rapporter/drogutvecklingen -i-sverige-2019/.

CAN. (2020). Skolelevers drogvanor 2020. Rapport 197. https:// www.can.se/publikationer/skolelevers-drogvanor-2020/.

Christie, N., \& Bruun, K. (1985). Den gode fiende. Narkotikapolitikk i Norden. Oslo: Universitetsforlaget.

Cohen, S. (1972). Folk devils and moral panics. The creation of the Mods and Rockers. Oxford: Blackwell.

De Preux, E., Dubois-Arber, F., \& Zobel, F. (2004). Current trends in illegal drug use and drug related health problems in Switzerland. Swiss Med Wkly, I34, 3 I3-32 I.

Doobs, A., \& Gartner, R. (2017). Understanding the impact of police stops. A report prepared for the Toronto Police Service Board, I7 January 20I7, Understanding the Impact of Police Stops I Centre for Criminology \& Sociolegal Studies (utoronto.ca).

Ds I992:19. Åtgärder mot bruk av narkotika samt ringa narkotikabrott. Stockholm: Justitiedepartementet.

Ds 2007:2. Frågan om fortsatt giltighet av 1952 års tvångsmedelslag och lagen om kameraövervakning, https://www.regeringen.se /49bb6r/contentassets/62869c4b8e 5640eI 89326783 boebo2a9 /-fragan-om-fortsatt-giltighet-av-ı 952 -ars-tvangsmedelslag -och-lagen-om-hemlig-kameraovervakning-ds-20072.

Edman, J., \& Olsson, B. (20I4). The Swedish drug problem: Conceptual understanding and problem handling, I839-20 I I. Nordic Studies on Alcohol and Drugs, 3I (5-6), 503-526. 
EMCDDA. (The European Monitoring Centre for Drugs and Drug Addiction) (2007). Statistical Bulletin 2007 (Problem drug use), http://www.emcdda.europa.eu/statso7/pdufigora.

EMCDDA. (The European Monitoring Centre for Drugs and Drug Addiction) (2019). Sweden. Country Drug report 2019, http:// www.emcdda.europa.eu/countries/drug-reports/2019/sweden.

Folkhälsomyndigheten. (2020). Åtgärdsförslag för att förebygga användning samt medicinska och sociala skadeverkningar av narkotika, https://www.folkhalsomyndigheten.se/publicerat-material /publikationsarkiv/aa/atgardsforslag-for-att-forebygga-anvand ning-samt-medicinska-och-sociala-skadeverkningar-av-narkotika? fbclid=IwAR 3 XC_rWWz78V6HKUf 4 XEt8a 5 uIA $7709 \mathrm{AjZo}$ BYuJYTZHBOiwbhZkrbt3dws.

Föreningen Tryggare Ruspolitik (nd.), https://www.tryggarerus politik.se/.

Gusfield, J. (1963). Symbolic crusade. Status politics and the American temperance movement. Urbana, Ill.: University of Illinois Press.

Hall, S., Critcher, C., Jefferson, T., Clarke, J., \& Roberts, B. (I978). Policing the crises. Mugging, the state, and law and order. London: McMillan.

Hari, J. (2015). Chasing the scream: The first and last days of the war on drugs. London: Bloomsbury Circus.

Hermansson, K. (2019). Symbols and emotions in Swedish crime policy discourse. Stockholm: Stockholm University, Department of Criminology.

Holgersson, S. (2007). Kartläggning av svenska polisens narkotikabekämpning. Rapport 23, Mobilisering mot narkotika.

Jareborg, N. (1995). What kind of criminal law do we want? In A. Snare (Ed.), Beware of punishment. On the utility and futility of criminal law. Scandinavian Studies in Criminology, Volume I4. Oslo: Pax.

Jerre, K., \& Tham, H. (2010). Svenskarnas syn på straff. Stockholm: Stockholms universitet, Kriminologiska institutionen. 
Johansson, M. (2020). Anförande på narkotikakonferens med fokus på förebyggande metoder och tidig upptäckt, https://www .regeringen.se/tal/2020/o5/anforande-av-morgan-johansson -pa-webbsand-narkotikakonferens-med-fokus-pa-forebyggande -metoder-och-tidig-upptackt/.

Johnson, B. (2003). Policyspridning som översättning. Den politiska översättningen av metadonbehandling och husläkare i Sverige. Lund Political Science I30. Lund: Lund University, Department of Political Science.

Johnson, B. (202I). Nils Bejerot och den svenska narkotikapolitiken. Lund: Arkiv.

Justitiedepartementet. (20I9). Uppdrag till Polismyndigheten att förstärka bekämpningen av illegal handel med narkotika. Regeringsbeslut 2019-08-I5. Ju2019/0268/PO.

Kriminalstatistik, https://www.bra.se/statistik/kriminalstatistik /personer-lagforda-for-brott.html.

Kriminalvården, https://www.kriminalvarden.se/forskning-och -statistik/statistik-och-fakta/anstalt/\#Missbruk.

Larsson, M. (201 2-05-20). Debatt. Expressen.

Leifman, H. (2016). Drug-related deaths in Sweden - Estimations of trends, effects of changes in recording practices and studies of drug patterns. CAN rapport I 28. Stockholm: CAN, Swedish Council for Information on Alcohol and Other Drugs.

Lenke, L. (I99I). Dryckesmönster, nykterhetsrörelser och narkotikapolitik. Sociologisk Forskning, 28(4), 34-47.

Linton, M. (201 5). Knark. En svensk historia. Stockholm: Atlas.

Local, The. Sweden's news in English (20 I 5-I I-8). UN:

Sweden's drug rules violate human rights, https://www .thelocal.se/20 I 5 I I 08 /un-swedish-drug-policy-violates-human -rights.

Månsson, J. (2017). Cannabis discourses in contemporary Sweden. Continuity and change. Stockholm Studies in Social Work 35. Stockholm: Department of Social Work, Stockholm University. 
Murray, K. (20I4). Stop and search in Scotland: An evaluation of police practice. SCCJR, The Scottish Centre for Crime \& Justice Research.

Olsson, B. (20I I). Reflektioner om narkotika som problem och politik - från vad till vad? In B. Olsson (Ed.), Narkotika. Om problem och politik. Stockholm: Norstedts Juridik.

Pettersson, T. (2005). Polisingripanden vid eget bruk av narkotika. Särbehandlas personer med utländsk bakgrund? Rapport 2005:2. Stockholm: Kriminologiska institutionen, Stockholms universitet.

Proposition I977/78:105. Om åtgärder mot narkotikamissbruk, https:/www.riksdagen.se/sv/dokument-lagar/dokument /proposition/om-atgarder-mot-narkotikamissbruk_Gio3 I05/html.

Proposition I983/84:I00. Förslag till statsbudget för budgetåret I $984 / 85$, https://www.riksdagen.se/sv/dokument-lagar/?q=narko tikafritt+proposition+I $983 \% 2 \mathrm{~F} 84 \%{ }_{3}$ A roo\&p= I \&st=2.

Proposition I98 5/86:I00. Förslag till statsbudget för budgetåret I 986/87, https://data.riksdagen.se/fil/ ${ }_{3} \mathrm{C}_{4} \mathrm{~B} 8 \mathrm{E} 2 \mathrm{~A}-446 \mathrm{D}-473 \mathrm{~A}$ -ABoI-4FI446302B22.

Proposition 2001/02: 9I. Nationell narkotikaplan, https://data .riksdagen.se/fil/9028DC59-EoE4-409D-AE22-3F27A4FBB68B.

Proposition 2009/IO:I05. Barn under I5 år som misstänks för brott, https://data.riksdagen.se/fil/ 5 A6C 5 E9D-B903-4Co6-8892 -A44FC9929FFE.

Proposition 20I 5/I6:I I I. Synnerligen grova narkotikabrott, https:// www.riksdagen.se/sv/dokument-lagar/dokument/proposition /synnerligen-grova-narkotikabrott_H303 I I I .

Proposition 20I6/I 7:I 5. Ökad tillgänglighet till sprutbytesverksamheten $i$ Sverige, https://data.riksdagen.se/fil/o579F6 $6{ }_{9} \mathrm{E}-\mathrm{B}_{3} 8 \mathrm{~A}$ -492B-8288-92249B4650B9.

Proposition 2020/2I:I32. En förnyad strategi för politiken avseende alkohol, narkotika, dopning, tobak och nikotin samt spel om pengar 202I-2025. prop-2020-2I-I32.pdf (regeringen.se).

Regeringskansliet. (1998). A preventive strategy. Swedish drug policy in the I990s. 
Regeringskansliet, Socialdepartementet. (2016). En samlad strategi för alkohol-, narkotika, dopnings och tobakspolitiken 2016-2020. Mål och insatsområden. Artikelnr S2016:002, https://www.regeringen.se/contentassets/ocb3c9b3 b28b4967 8a7205a3672b3e85/rk_2I340_socialdep_folder_tillg_web.pdf.

Rättsmedicinalverket, årsredovisning. (2020). https://www.rmv .se/wp-content/uploads/A\%CC\%8Arsredovisning-2020-tillg $\% \mathrm{C}_{3} \%$ A4nglighetsanpassad-2 I03 I I.pdf.

Rättsstatistisk årsbok 1993, Stockholm: Statistics Sweden.

SIFO. (I984). Allmänheten vill förbjuda all befattning med narkotika. Mimeo.

SKL, Sveriges kommuner och landsting. (2018). Handlingsplan mot missbruk och beroende, https://webbutik.skr.se/bilder/artiklar /pdf/7585-664-3.pdf? issuusl=ignore.

Socialdemokraterna (2018). Kriminalpolitiskt program, https://www .socialdemokraterna.se/download/I 8. I 2ce 54 f I 6 be 946 do 4640 da8/I 56888 I 6I 8024/kriminalpolitiskt-program-20 I 8-06-07.pdf.

Socialutskottet 20I9/20, Socialutskottets betänkande 20I9/20: $\mathrm{SoU}_{7}$, Alkohol-, narkotika-, dopnings- och tobaksfragor, https://data.riksdagen.se/fil/38 A67 $\mathrm{C}_{5} \mathrm{~A}-\mathrm{A} 09_{2}-4 \mathrm{E}_{3} \mathrm{~F}-9 \mathrm{~B}_{1} 5$ -EI $8 \mathrm{~B}_{2} \mathrm{~B}_{72} \mathrm{CA} \circ \mathrm{A}$.

SOU 2000:I 26. Vägvalet. Den narkotikapolitiska utmaningen. Slutbetänkande av Narkotikakommissionen. PM nr 3 Narkotikarelaterad död. Stockholm: Fritzes Offentliga Publikationer.

SOU 2021:68. Skärpta straff för brott $i$ kriminella nätverk. Betänkande av Gängbrottsutredningen. Stockholm: Regeringskansliet.

Svedberg, J., \& Svensson, R. (I995). Telefonavlyssning som tvångsmedel. En undersökning av teleavlyssningens omfattning och effektivitet angående den öppna polisen. BA thesis. Stockholm: Kriminologiska institutionen, Stockholms universitet.

Swedish drug policy - a balanced policy based on health and human rights (nd.). Government Office of Sweden. Ministry of Health and Social Affairs, https://www.government.se/496f 5 b/contentas 
sets/89b8540 Iеd204484832fb I 808cad60 I 2/rk_2 I I64_broschyr _narkotika_a4_en_3_tillg.pdf.

Swedish National Institute of Public Health. (1993). A restrictive drug policy. The Swedish experience. Report I993:4. Stockholm.

Swedish National Institute of Public Health. (I998). A preventive strategy. Swedish drug policy in the I990s. Report I998:2 I. Stockholm.

Swiss Health Observatory. Drug related deaths, https://www.obsan .admin.ch/en/indicators/MonAM/drug-related-deaths. https:// www.obsan.admin.ch/en/indicators/MonAM/drug-related-deaths.

Tham, H. (I995). Drug control as a national project: The case of Sweden. The Journal of Drug Issues, $25(\mathrm{I}), \mathrm{I}_{3} 3^{-\mathrm{I}} 28$.

Tham, H. (2005). Swedish drug policy and the vision of the good society. Journal of Scandinavian Studies in Criminology and Crime Prevention, 6(I), 57-73.

Tham, H. (20I2). The influence of the drug issue on criminal policy. Journal of Scandinavian Studies in Criminology and Crime Prevention, I3 (Supplement I), I2-30.

Tham, H. (2018). Kriminalpolitik. Brott och straff $i$ Sverige sedan 1965. Stockholm: Norstedts Juridik.

van Fessem, E. (1996). Black and white in the Swedish drug issue. The opinion machine at work. School of Social work, Stockholm University; Faculty of Social Sciences/Crises Research Centre (COT), Erasmus University Rotterdam/Leiden University.

Wallström, M. (I998). Svenskar måste förklara knarkupprop. DN Debatt. Dagens Nyheter I998-06-2I. 